\title{
DEPOSITION VELOCITY OF PHOSPHORUS-CONTAINING PARTICLES OVER SOUTHERN LAKE HURON, APRIL-OCTOBER, 1975
}

\author{
R. Delumyea ${ }^{*}$ and R. L. Petel $\dagger$ \\ Great Lakes Research Division, The University of Michigan, Ann Arbor, MI 48109, U.S.A.
}

(First received 8 December 1977 and in final form 29 August 1978)

\begin{abstract}
Total mass, phosphorus concentration and the size distribution of phosphorus-containing particles were determined. Samples were collected aboard the R/V Roger R. Simons and at eleven land-based stations from April to October, 1975. Based on cross-lake mass and phosphorus concentration gradients, size distribution and vertical profiles, a mixing box model was used to determine a deposition velocity for phosphorus-containing particles of $0.57 \mathrm{~cm} \mathrm{~s}^{-1}$.
\end{abstract}

\section{INTRODUCTION}

Phosphorus has been determined to be the limiting nutrient in the Great Lakes system (Schelske et al., 1971 ; 1972). The amount of phosphorus entering the lakes from the atmosphere has been the subject of recent investigations. Murphy (1974) considered only wet inputs (rain, snow, etc.); whereas Acres (1975) and Elder (1975) estimated both wet and dry depositions. The determination of the actual dry deposition is difficult since samplers are most easily located on shore and therefore subject to local contamination. Nevertheless, dry deposition represents an important input mechanism since all material entering the lake by this method must pass through the euphotic zone. Further, in contrast to the sporadic nature of wet inputs, dry deposition is a continuous process.

To determine the input due to dry deposition, the sampling scheme in the present study was designed to supply data for a simple mixing box model of particle deposition. Considering the assumptions necessary for such a model, a lake surface may be the ideal place to determine deposition velocities. The assumptions involved are: a constant mixing height; a complete sink at the bottom of the box; complete mixing of the contents; no sources of the aerosol in the box; a constant deposition velocity; and knowledge of wind direction. Aerosol samples were collected aboard the $\mathbf{R} / \mathbf{V}$ Roger $R$. Simons and at eleven land-based sampling stations located at approximately 25 mile intervals along the lake shore. The two-letter codes for the stations, shown in Fig. 1, are as follows: Lighthouse County Park (LT), Wagener County Park (WG), Sanilac County Park No. 1 (S1), Sanilac County Park

* Author to whom correspondence may be addressed. Present address: Department of Chemistry, Washington University, St. Louis, MO 63130, U.S.A.

† Present address: Health Physics Research Division, Philippines Atomic Energy Commission, Don Mariano Marcos Avenue, Diliman, Quezon City, Philippines.
No. 2 (S2), Lakeport State Park (LP), in Michigan; Ipperwash Provincial Park (IP), St. Joseph Shores (SJ), Bayfield Marina (BY), Point Farms Provincial Park (PF), Point Clark Boat Club (PC), Inverhuron Provincial Park (IN) in Ontario; and the mid-lake anchoring station for the Roger R. Simons, (SLH). Total aerosol loading, particle size distribution and phosphorus content of the aerosol were determined. Vertical profiles of particle concentration were determined from nephelometric data obtained with an instrumented B-26 aircraft. Phosphorus was analyzed in three forms, based on potential uptake in the lake : the phosphorus soluble in water is referred to as "soluble"; acid soluble $(\mathrm{pH}=2)$ as "reactive" and insoluble as "bound". The sum of soluble and reactive is termed "available" phosphorus.

\section{EXPERIMENTAL}

\section{Equipment}

Gelman Air Sampling Kits (Bendix Environmental Science Division, 1400 Taylor Avenue, Baltimore, MD) were modified by the addition of timers, relocation of the flowmeters, and installation of locks and chains. These pumps were used to collect samples on $37 \mathrm{~mm}$ glass fiber filters and Andersen cascade impactor samples. Samples were collected at the top of a $5 \mathrm{~m}$ mast, were facing downward and were protected by a plastic rain shield. High volume air samplers (General Metal Works, 8368 Brigetown Road, Cleves, $\mathrm{OH}$ ) were used to collect total aerosol samples. The mats were weighed to constant weight before and after sample collection to determine the total weight gained through aspiration of a known volume of air. From this, the total concentration of particulate matter in the air was determined.

\section{Sampling}

The research vessel Roger $R$. Simons was anchored on station in Lake Huron for one 24-h period each month from April to October. While on station the ship was anchored at the bow and only one generator was run, to reduce the possibility of contamination from ship exhaust. Samples which appeared excessively black, or which were collected when the shipboard windvane indicated a windspeed of less than $5 \mathrm{~km} \mathrm{~h}^{-1}$ were excluded from the data set. During this period a 24-h Hi-Vol sample, an Andersen sample, and three consecutive 8-h 


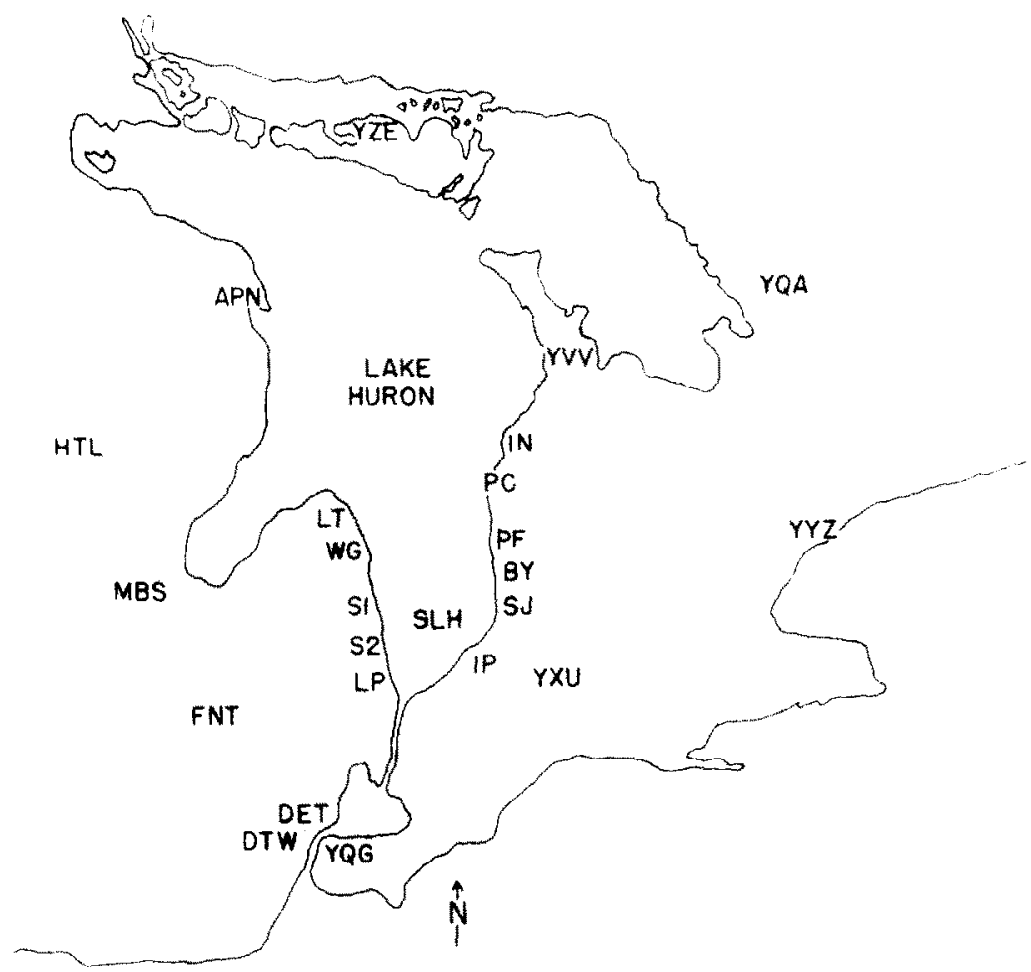

Fig. 1. Location of sampling and meteorological stations. Two-letter codes designate sampling stations on the Lake Huron shore and three-letter codes indicate weather stations.

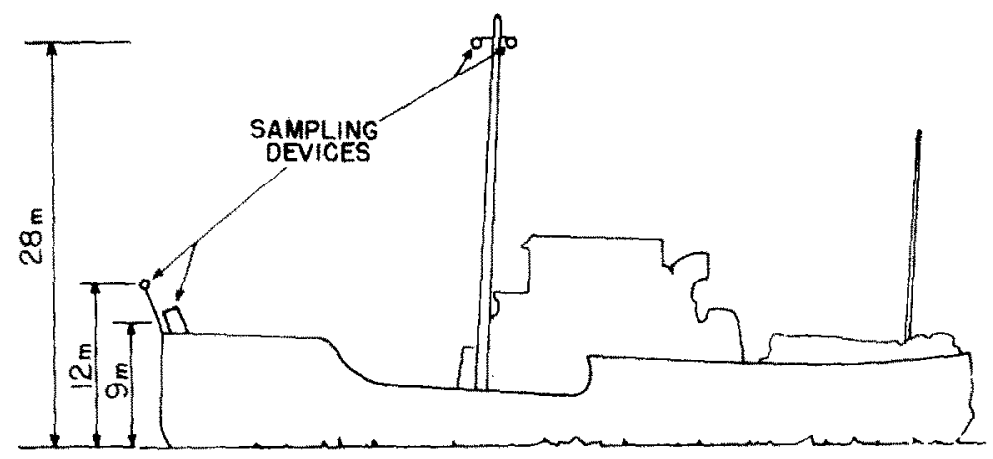

Fig. 2. Location of sampling devices aboard the R/V Roger $R$. Simons.

Gelman samples were collected. Samplers were located on the ship as shown in Fig. 2. The eleven land-based samplers were run for 8 -h periods followed by a 4 -h down-time during which flow rates and vacuum pressure were recorded and new filters installed. The pumps were activated by a timing device to run from 1000 to $1800 \mathrm{~h}$ and from 2200 to $0600 \mathrm{~h}$ the following day. Table $I$ summarizes the sampling scheme.

Table 1

\begin{tabular}{|c|c|c|c|c|}
\hline $\begin{array}{l}\text { Sampling } \\
\text { device }\end{array}$ & $\begin{array}{c}\text { Flow } \\
\text { rate } \\
\left(1 \mathrm{~min}^{-1}\right\}\end{array}$ & $\begin{array}{c}\text { Sampling } \\
\text { time } \\
\text { (b) }\end{array}$ & Collector & $\begin{array}{l}\text { Station } \\
\text { code }\end{array}$ \\
\hline $\begin{array}{l}\text { Gelman air } \\
\text { sampling kits }\end{array}$ & 42 & 8 & $\begin{array}{l}\text { Glass fiber } \\
\text { filter }\end{array}$ & All stations \\
\hline $\begin{array}{l}\text { Andersen } \\
\text { cascade impactors }\end{array}$ & 28 & 12 & $\begin{array}{l}\text { Durethane } \\
\text { plate }\end{array}$ & PF, SLH \\
\hline Hi-Vois & 1420 & $8-12$ & $\begin{array}{l}\text { Glass fiber } \\
\text { filter }\end{array}$ & LT. SL.H \\
\hline
\end{tabular}

Sample preparation and analysis

Phosphorus was measured as orthophosphate using a molybdenum-antimony-ascorbate procedure Murphy, 1962). This standard heteropoly acid method was automated with a Technicon ${ }^{\mathrm{R}}$ AutoAnalyzer(II). The persulfate digestion procedure for total phosphorus was a modification of the method of Menzel and Corwin (1965) and digestion blanks and standards were analyzed with the digested samples.

Prior to use, all glassware was soaked in $10 \%$ sulfuric acid for a minimum of $2 \mathrm{~h}$ and multiply rinsed with distilled water. Single distilled water was used in the preparation of all reagents, extraction of the filters and dilution of samples. The concentration of phosphorus in the water was routinely monitored. For extraction, a glass fiber filter was placed in a $60 \mathrm{ml}$ suction flask. Ten 2 -ml volumes of distilled water were aspirated through the filter under slightly negative pressure. The filtrate was quantitatively transferred to a $25 \mathrm{ml}$ volumetric flask containing two drops of concentrated sulfuric acid and diluted to volume with distilled water. The phosphorus in this solution was termed "soluble phosphorus". The extrac- 
tion was then repeated using ten $2 \mathrm{ml}$ aliquots of $\mathrm{pH}=2$ sulfuric acid. This filtrate was transferred to a $25 \mathrm{ml}$ volumetric flask (no acid present) and diluted to volume with $\mathrm{pH}=2$ solution. This fraction was termed "reactive phosphorus" and the sum of the two considered "available phosphorus". At least three unexposed filters were treated as described above each month to serve as blanks. Persulfate acid digestions were performed on extracted samples to determine "bound" phosphorus concentrations. A filter was placed in a $250 \mathrm{ml}$ beaker, $10 \mathrm{ml}$ of distilled water and 10 drops of concentrated sulfuric acid added and the sample heated to approx $100^{\circ} \mathrm{C}$, $5 \mathrm{ml}$ of $5 \%$ ammonium persulfate added, and the sample evaporated to dense fumes. After cooling, the solution was filtered through a fine porosity sintered glass funnel into a $25 \mathrm{ml}$ volumetric flask, which was diluted to volume with rinse solution.

\section{Meteorological data}

Meteorological data were supplied by the National Weather Service Forecast Office at Detroit Metropolitan Airport, Detroit, Michigan. Teletype outputs of the Service A reports, consisting of hourly observations of temperature, dew point, wind speed, wind direction, precipitation, and cloud cover, were provided for all Michigan and Ontario weather stations.
Using these data, resultant wind speed and direction vectors were calculated for the $4 \mathrm{~h}$ preceeding and the $8 \mathrm{~h}$ of sampling for each of twelve meteorological stations. Although some of the stations were removed from the shores of southern Lake Huron, the overall wind speeds and directions were used to provide an indication of the flow of large air masses in the southern Lake Huron basin. Meteorological data were also obtained on the Roger $R$. Simons when it was on station.

\section{Aircraft sampling}

Using an instrumented B-26 aircraft (National Environmental Research Center, EPA, Las Vegas, Nevada), vertical profiles of particle concentration were obtained from nephelometric data collected during downward spirais. A plot of a typical spiral, collected during mid-September, is shown in Fig. 3. From these data, the mean height of the mixing layer was found to be approx $1200 \mathrm{~m}$ above the lake surface. This value agrees with that obtained from rawinsonde data (Portelli, 1977) for the mean afternoon maximum mixing heights in summer over the southern portion of Canada, including the Great Lakes, of $1200-1300 \mathrm{~m}$. The value of $1200 \mathrm{~m}$ was used in the calculation deposition velocities as discussed below.

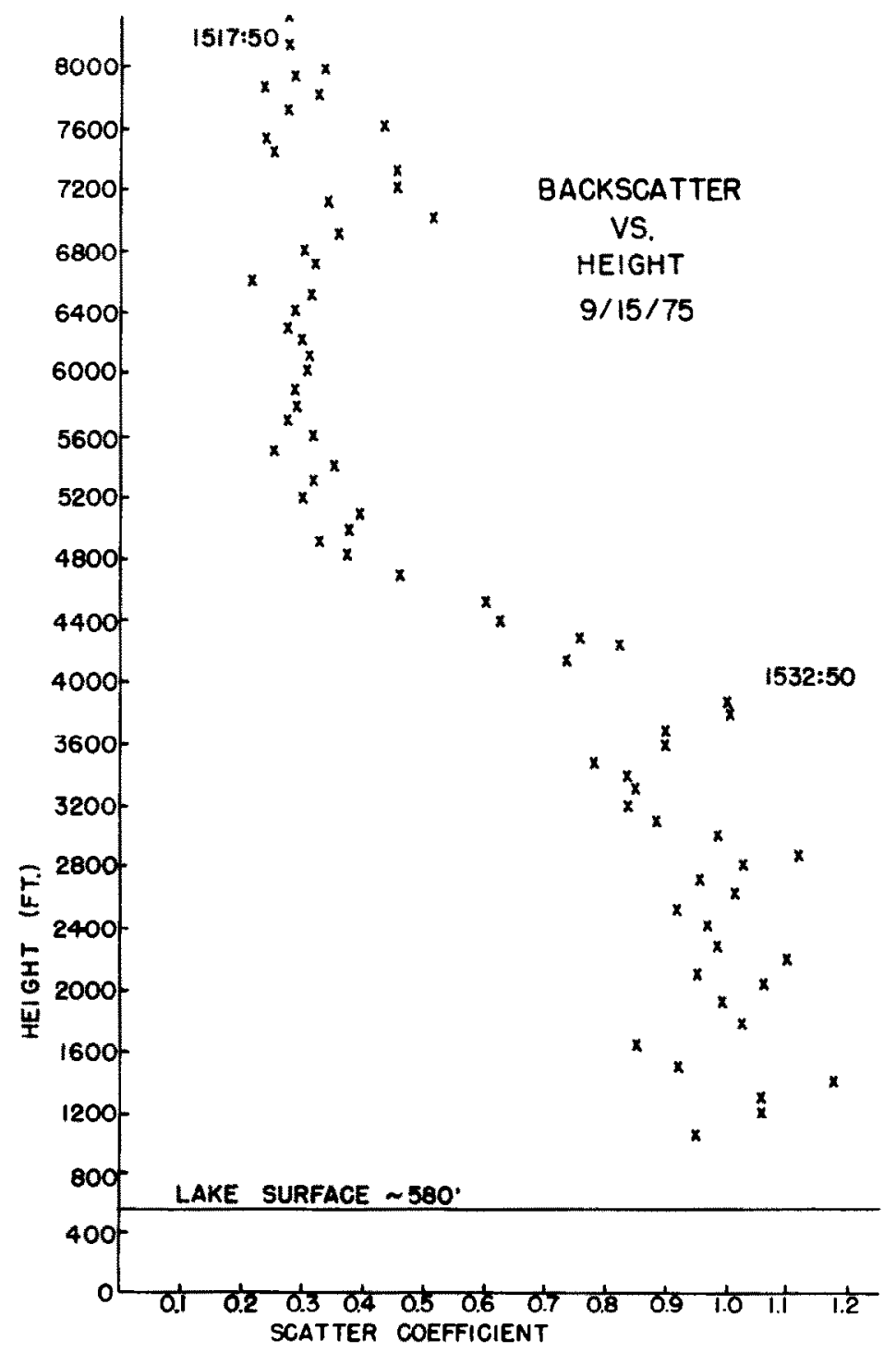

Fig. 3. Nephelometric data from aircraft. The height of the mixing layer was approx $1200 \mathrm{~m}$ above the lake surface. 
RESULTS AND DISCUSSION

\section{Total aerosol loading}

The total loadings determined aboard the Roger $R$ Simons (SLH) and at Lighthouse County Park (LT) are given in Table 2 for all periods when both stations were operating. Since the Roger $R$. Simons was only on station for $24 \mathrm{~h}$, and bad weather caused lost data in August and October, the number of samples is small. Nevertheless, the existence of a cross-lake aerosol gradient is indicated by comparison of the difference in aerosol concentrations at the two sites with wind direction, also listed in Table 2. In the first four cases, the Roger $R$. Simons was downwind from the Lighthouse station and obtained a lower aerosol concentration. In the fifth case, however, the Roger $R$. Simons was upwind and obtained a higher concentration than the land-based sampler. The 9-10 July samples were taken following a period of heavy rain and while the concentration was greatly reduced, the gradient was found to continue.

\section{Particle size distribution of phosphorus}

Due to the relatively small amounts of phosphorus anticipated on each stage, the 24-h Andersen samples were collectively digested by stage for each month. As a result, the minimum sampling time was $72 \mathrm{~h}$. Backup filters were not analyzed and therefore particles $<0.1 \mu \mathrm{m}$ were not routinely collected. In August and September, eight-stage Andersen samples were collected which indicate that a significant $\left(>10_{\%}^{\circ}\right)$ fraction of phosphorus was contained on the particle
Table 2.

\begin{tabular}{lccc}
\multicolumn{1}{c}{ Date } & $\begin{array}{c}\mathrm{LT} \\
\text { conc } \\
\left(\mu \mathrm{g} \mathrm{m}^{-3}\right)\end{array}$ & $\begin{array}{c}\text { SLH } \\
\text { conc } \\
\left(\mu \mathrm{g} \mathrm{m}^{-3}\right)\end{array}$ & $\begin{array}{c}\text { Wind } \\
\text { direction } \\
\text { (degrees) }\end{array}$ \\
$\begin{array}{l}\text { 12-13 June } \\
\text { 9 July }\end{array}$ & 39.0 & 27.3 & 34 \\
9-10 July & 19.7 & 11.4 & 112 \\
15-16 September & 7.2 & 1.1 & 100 \\
16 September & 59.5 & 61.8 & 51 \\
& 50.3 & 56.0 & 332
\end{tabular}

$<0.1 \mu \mathrm{m}$. The mass median diameter is approx $1 \mu \mathrm{m}$. with at least $28.5 \%$ of the phosphorus found on particles less than $0.5 \mu \mathrm{m}$. The particle size distribution is marginally bimodal for all months as seen in Fig. 4. From the mass median diameter, it appears that the most significant fraction is due to continental erosion.

\section{Determination of deposition velocity}

The concentration of available phosphorus in the aerosol samples collected at each station was determined. It was observed that in the majority of cases. the stations located on the downwind shore collected a lower amount of phosphorus than those on the upwind shore of Lake Huron. This observation is best illustrated by the month of June (Fig. 5). During the sampling period, the wind originated in the southeast and blew across the lake for four consecutive periods, turned south with no crosswind component for one period and then blew from the southwest for the last two sampling periods. There were therefore four periods during which the Canadian shore was upwind

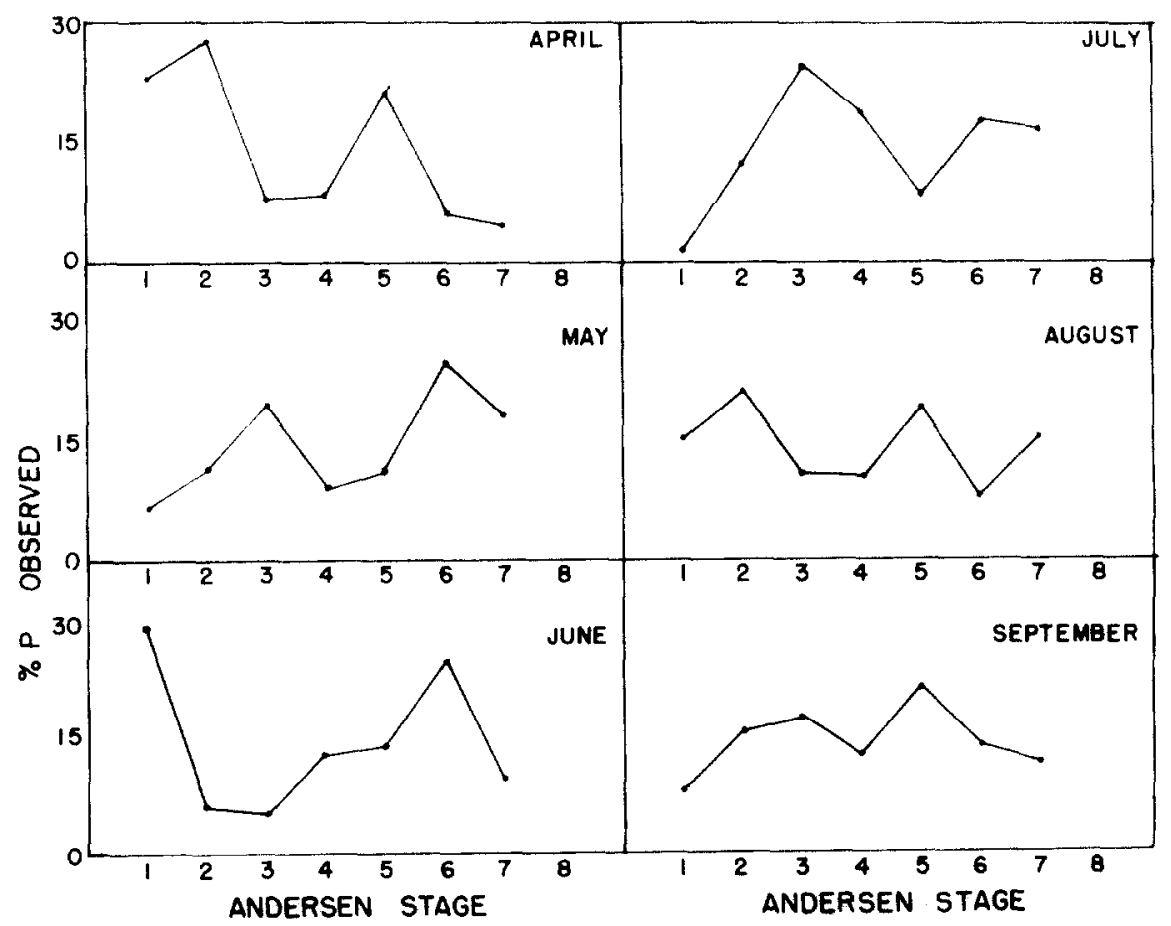

Fig. 4. Size distribution of phosphorus-containing particles. The size ranges for stages 1.7 are : $>4.6,2.9-4.6$, $1.6-2.9,0.9-1.6,0.5-0.9,0.3-0.5$ and $0.1-0.3 \mu \mathrm{m}$, respectively. 


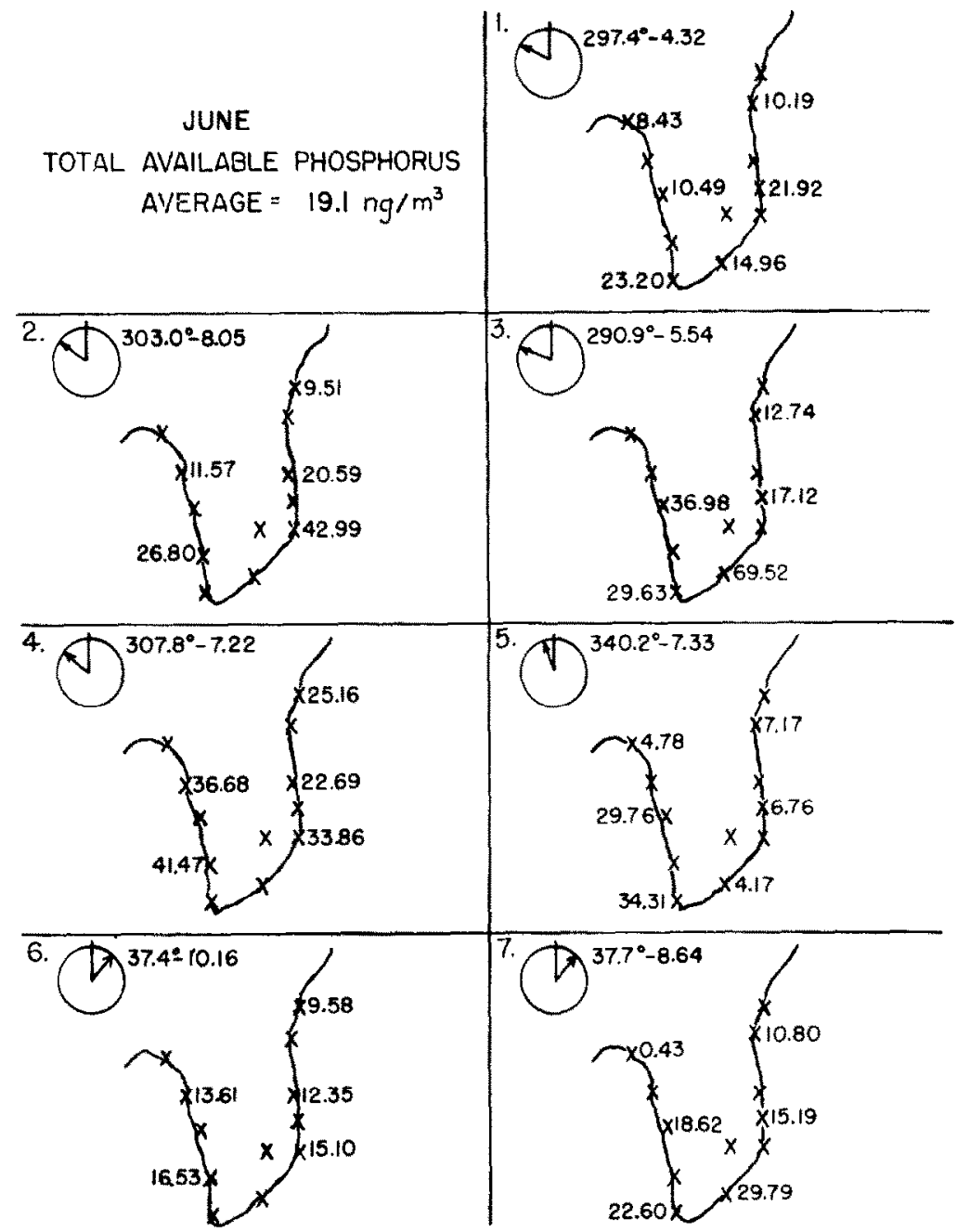

Fig. 5. Aerosol phosphorus concentration. Figure shows wind direction and speed in upper left corner of each sampling period, and concentration of each station in $\mathrm{ng} \mathrm{m}^{-3}$.

and two periods when the American shore was upwind. Except for the last Canadian upwind samples when the wind was swinging southward, the downwind stations observed a lower phosphorus content in the air, establishing that a definite cross-lake concentration gradient exists for the aerosol. To attempt to quantify this observation, pairs of sampling stations, one on each shore, were selected which were in a line parallel to the wind direction and those samples were compared. In five cases (the first three Canadian upwind and the two American shore upwind), the ratio of downwind to upwind phosphorus contents of the aerosol, $\mathrm{C} / \mathrm{Co}$, was in the range of $0.4-0.8$, even though rain occurred during two of these periods. This value appeared to vary with wind speed. Further, $\mathrm{C} / \mathrm{Co}$ was independent of the magnitude of the concentrations, which ranged from an average of $13.4-33.2 \mu \mathrm{g} \mathrm{m}^{-3}$ Although the effect of wind direction could not be determined, the effect of wind speed was found to be significant. When the ratio $\mathrm{C} / \mathrm{Co}$ was plotted against wind speed, it was observed that the ratio increased with increasing wind speed. In other words, the faster the wind blew, the smaller the fraction of the aerosol fell out due to the decreased residence times of the aerosol over the lake. These values of $\mathrm{C} / \mathrm{Co}$ were then used to calculate deposition velocities for each period using the simple box model shown in Fig. 6 . The assumptions made in this model are: (1) a constant mixing height; (2) a complete sink at the bottom ; (3) complete mixing of the components in the

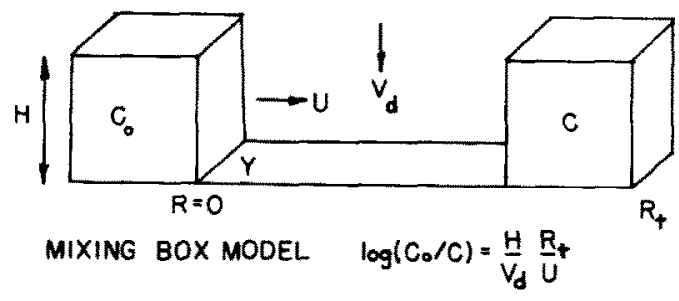

Fig. 6. Mixing box model used in calculation of deposition velocity. 
box; (4) constant deposition velocity; and (5) known wind direction. Under these conditions. the equation for the deposition is:

$$
\log (C / C o)=\frac{V_{d} R_{t}}{H U}
$$

where:

$$
\begin{aligned}
V_{d} & =\text { deposition velocity; } \\
H & =\text { height of mixing layer } \\
C & =\text { downwind concentration: } \\
C O & =\text { upwind concentration; } \\
R_{t} & =\text { distance between sampling stations; } \\
U & =\text { wind speed. }
\end{aligned}
$$

The height of the mixing layer was determined from aircraft data on backscatter as a function of height ; the concentrations upwind and downwind were determined from samples collected on the two shores; the distance between the samplers was known; and the wind speed was determined from National Weather Service data and from data obtained aboard the Roger R. Simons.

Of the approximately 45 sampling periods, 30 had a cross-lake wind direction which intersected at least one sampling station on each shore. Of these 30,25 pairs had a value of $C / C o$ less than unity. The remainder were considered to be contaminated by local sources and were not considered in the statistical treatment of the data. Using the remaining 25 sampling sets, the above calculation gave a deposition velocity of $0.57 \mathrm{~cm} \mathrm{~s}^{-1}$ with a $90_{\%}^{\circ}$, confidence limit of $\pm 0.16 \mathrm{~cm} \mathrm{~s}^{-1}(n=25)$. The calculation was refined by recalculating each sample using the monthly mean maximum mixing depth obtained by Portelli (1477). The recalculated value was $0.56+0.15 \mathrm{~cm} \mathrm{~s} \quad(n=24)$. The results are listed in Table 3.

It has been observed that under certain meteorolog!cal conditions, a stable boundary layer can form, isolating the lake surface from the atmosphere. This "decoupling" occurs when the winds are low and the water temperature is significantly lower $(5 \mathrm{C}$, arbitrarily) than the air temperature. Such decoupling causes the actual deposition of gases and particles to be reduced during such stable periods, particularly in summer. Hicks (1978) has addressed the question of how often decoupling is likely to exist on the Great Lakes. Lake Huron was found to be highly unstable during the months from October to March and potentially stable during the period from May to July. Even during the period of potential stability, decoupling only occurs at low windspeeds (arbitrarily $<5$ miles $\left.\mathrm{h}^{-1}\right)$ and during the day ( $\Delta T$ decreases at night).

To assess the potential impact of meteorological stability conditions over the lake surface on the deposition velocity calculation, a "poor man's stability index", defined as :

Table 3. Calculation of deposition velocity, $V_{d}$

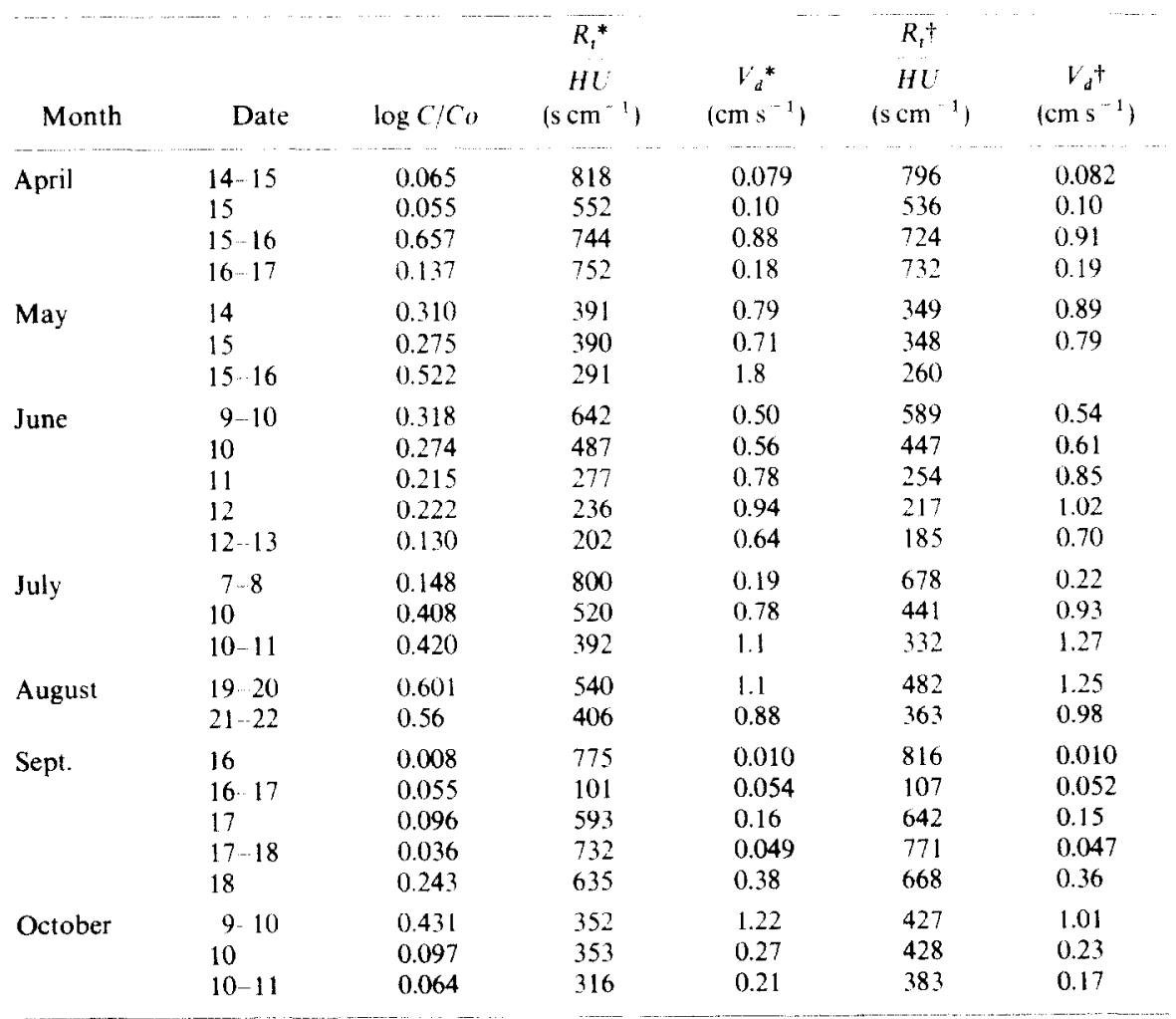

* Calculated using $H=1200 \mathrm{~m}$. Average $=0.57 \pm 0.16$ at $90 \%$ confidence.

+ Calculated using monthly values for $\boldsymbol{H}$ from Portelli. Average $=0.56 \pm 0.15$ at $90 \%$ confidence. 


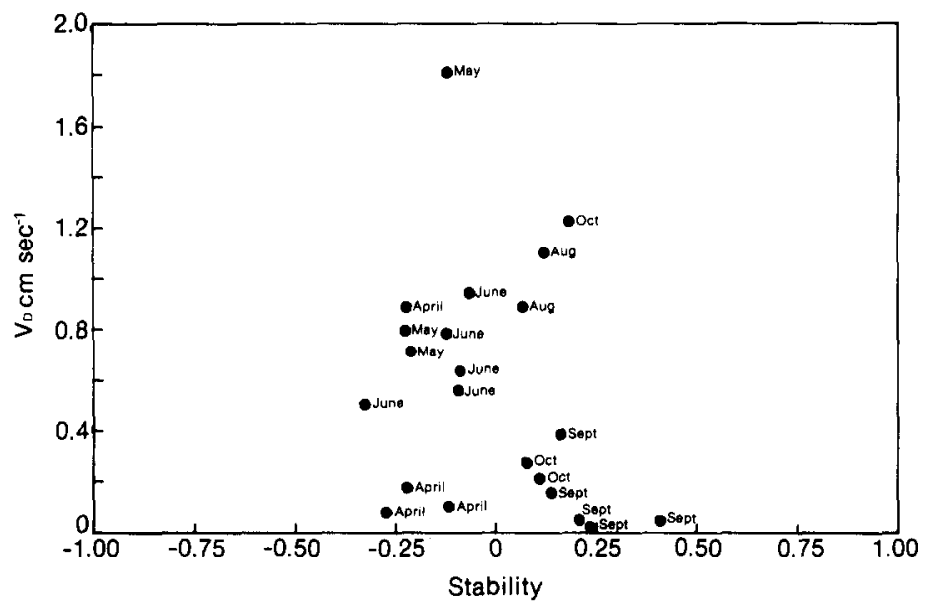

Fig. 7. Comparison of $V_{d}$ with stability. July data not included since $\Delta T$ not known.

$$
\text { Stability }=\frac{\Delta T}{U^{2}}
$$

where

$$
\Delta t=\text { (lake temperature-air temperature) }
$$

and

$$
U=\text { wind speed, }
$$

was calculated. Wind speed values were obtained from our data and air and lake temperatures taken from the data of Hicks (1978). A plot of the deposition velocity $\left(V_{d}\right)$ against stability (Fig. 7) showed a low correlation $(r=-0.24, n=22)$. Slopes of $V_{d}$ vs stability for each month varied from -0.8 to +10.8 . It is possible, however, that since the calculated $V_{d}$ values may have been obtained from samples collected during unfavorable stability conditions, this comparison may be misleading. Comparison of the calculated $V_{d}$ values with wind speed likewise gave little correlation as shown in Fig. 8. The well-mixed assumption should hold for night-time samples in the summer and at wind speeds in excess of 5 miles $\mathrm{h}^{-1}$. Thus, even assuming

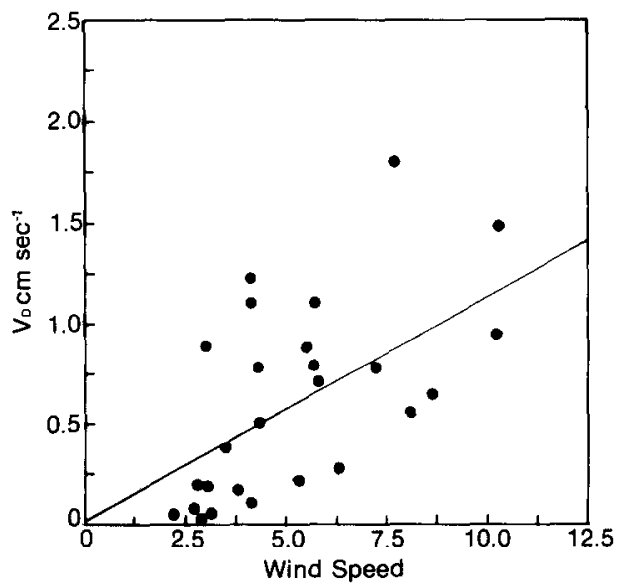

Fig. 8. Comparison of $V_{d}$ with wind speed for all values of $V_{d}$. the worst-case conditions of complete decoupling during the day and no winds in excess of 5 miles $h^{-1}$ during the three summer months, the resulting values of $V_{d}$ would be in error by a maximum of a factor of less than 2.

Wind tunnel studies conducted by Sehmel and Sutter (1974) using monodisperse particles of uranine (density $=1.5$ ) gave a deposition velocity for $1 \mu \mathrm{m}$ particles of $0.01 \mathrm{~cm} \mathrm{~s}^{-1}$. This value was used by Sievering (1976) to estimate loadings to Lake Michigan. In contrast, the deposition velocity assumed by Winchester and Nifong (1971) to estimate trace clement inputs to Lake Michigan in this size range was $0.5 \mathrm{~cm} \mathrm{~s}^{-1}$. Their original "transfer efficiency", defined as the fraction of the upwind aerosol which enters the lake, was estimated to be $10 \%$. Skibin (1973) raised this estimate to $25 \%$. The value observed in the present study was approx $30 \%$. In a study of total dry deposition in the Lake St. Clair region, Whelpdale (1974) calculated a flux of $1.7 \mu \mathrm{g} \mathrm{cm}^{-2}$ day $^{-1}$. Using $\mathrm{Hi}-\mathrm{Vol}$ data from the present study, the flux of total aerosol can be calculated from the simple equation: Flux $=$ Conc. $\times V_{d}$. Using this equation and the deposition velocity $0.57 \mathrm{~cm} \mathrm{~s}^{-1}$ from the present study, fluxes from 0.6 to $2.7 \mu \mathrm{g} \mathrm{cm}^{-2} \mathrm{day}^{-1}$, averaging $1.4 \mu \mathrm{g}$ $\mathrm{cm}^{-2}$ day $^{-1}$ were found. The agreement between the two studies is good. The value of $0.57 \mathrm{~cm} \mathrm{~s}^{-1}$ was used to calculate dry deposition of phosphorus to southern Lake Huron which was combined with wet deposition of phosphorus and compared with total integrated fallout (Delumyea and Petel, 1977; 1978). The results of that study compared well with a similar study conducted by the International Joint Commission (1977). In a study of the deposition of approximately 20 elements to Lake Windemere in England, Perison et al. (1973) determined crude deposition velocities by dividing the deposition rate in units of $\mu \mathrm{g} \mathrm{cm}^{-2} \mathrm{~s}^{-1}$ by the atmospheric concentration in units of $\mu \mathrm{g} \mathrm{cm}^{-3}$. For the 14 elements for which full data were available, the $V_{d}$ was found to average $0.35 \pm 0.11 \mathrm{~cm} \mathrm{~s}^{-1}$, varying from 0.1 to $0.7 \mathrm{~cm} \mathrm{~s}^{-1}$. Phosphorus was not 
among the elements in the study; however, the deposition velocity of phosphorus-containing particles should be similat.

\section{SUMMARY}

Using a mixing box model, the deposition velocity of phosphorus-containing particles was calculated. The mass median diameter of these particles is approx $1 \mu \mathrm{m}$, with $10 \%$ less than $0.1 \mu \mathrm{m}$ in size. The calculated deposition velocity of $0.57 \mathrm{~cm} \mathrm{~s}^{-1}$ is higher than wind tunnel data but is consistent with estimates used in previous work, with total deposition and dry deposition from previous studies and with experiments conducted around a freshwater lake in England.

Acknowledgements - - This work was supported by the U.S. Environmental Protection Agency as part of a grant (No. R803-086) to the Great Lakes Research Division of the University of Michigan. Copies of the report are available as Contribution No. 242 from the GLRD library. Our thanks are also extended to James V. Murphy, Captain of the R/V Roger R. Simons and his crew for their help in collecting overthe-lake samples; to Chas. Fitzsimmons of the EPA-National Environmental Research Center, Las Vegas, Nevada, and his crew for collecting the aircraft data; to C. Robert Snider of the U.S. Weather Service Forecast Office, Detroit Metropolitan Airport, for supplying the meteorological data ; and to B. B. Hicks, Argonne National Laboratory, Argonne, Illinois and J. M. Hales, Battelle Pacific Northwest Laboratories, Muskegon. Michigan for assistance in preparation of this manuseript.

\section{REFERENCES}

Acres Consulting Services Ltd. (1975) Atmospheric loading of the upper Great Lakes. Canada Centre Inland Waters, Vol. 2, p. 126, Burlington, Ont.

Delumyea R. G. and Petel R. L. (1977) Atmospheric inputs of phosphorus to southern Lake Huron, April-October, 1975. USEPA Report No. 660/3-77-038.

Delumyea R. G. and Petel R. L. (1978) Wet and dry deposition of phosphorus into Lake Huron. Wat. Air Soil Pollut 10 (in press)
Elder F. C. (1975) International Joint Commission Program for Atmospheric Loading of the Upper Great Lakes, Presented, Second Interagency Committee on Marine Science and Engineering Conference on the Great Lakes, Argonne, III

Hicks B. B. (1978) On the parameterization of aerosol fluxes to the Great Lakes. Im. J. Great Lake's Res. (in press.

Menzel D. W. and Corwin N. (1965) The measurement of total phosphorus in sea water based on the liberation of organically bound fractions by persulfate oxidation. Limnol. Oceanogr. 10, 280282

Miller W. E., Maloney T. E. and Green J. C. (1974) Algal productivity in 49 lake waters. Water Res. 8, 667079 .

Murphy J. and Riley J. P. (1962) Modified single solution method for the determination of phosphate in natural waters. Anal. Chim. Acta 27, $31-36$.

Murphy T. J. (1974) Sources of Phosphorus Inputs from the Atmosphere and their Significance to Oligotrophic Lakes. Univ. Illinois, Urbana, Water Resources Research Center, Rep. No. 92

Portelli R. V 1977. Data on Mixing Heights, Wind Speeds and Ventilation Coefficients for Canada, Internal Report No. ARQT-4-76. Atmospheric Environment Service. Downsuiew, Ontario, Canada.

Schelske C. L. and Stoermer E. F. (1971) Eutrophication, silica depletion and predicted changes in algal quantity in Lake Michigan. Science 173, 423--424

Schelske C. L. and Stoermer E. F. (1972) Phosphorus, silica, and eutrophication of Lake Michigan. In Nutrients ant Eutrophication. p. 157 171. (Edited by G. E. Likens) Allen Press. Lawrence. Kansas.

Schelske C. L., Feldt L. E. Santiago M. A. and Stoermer E. F. (1972) Nutrient enrichment and its effect on phytoplankton production and species composition of Lake Superior. Proc. 15th Conf. Great Lakes Res. 149-165.

Sehmel G. A. and Sutter S. L. (1974) Particle deposition rates on a water surface as a function of particle diameter and air velocity. I. Rech. utmos. 8, $911-920$

Sievering H. (1976) Dry deposition loading of Lake Michigan by airborne particulate matter. Wat. Air Soil Pollat. 5 , $309 \div 318$.

Skibin D. (1973) Comment on water pollution in Lake Michigan from pollution aerosol fallout. Wat. Air Soil Pollut. 2, 405-407

Whelpdale D. M. (1974) Particulate residence times. Wut. Air Soil Pollut. 3, 293 300)

Winchester J. W. and Nifong G. D. (1971) Water pollution in Lake Michigan by trace elements from pollution aerosol fallout. Wat. Air Soil Pollut. 1, 50 64. 